\title{
INTERNALISASI NILAI AKHLAKUL KARIMAH DALAM MEMBENTUK KARAKTER ANAK
}

Ali Muhsin

University of Pesantren Tinggi Darul Ulum

Abstrak: Panti Asuhan Muhammadiyah Dlanggu Mojokerto menjadi tempat untuk mendidik anak-anak yang kurang beruntung dalam pengajaran dari orang tuanya, karena didapatkan permasalahan dari 40 anak, ada yang suka membangkang, yang suka tidak menaati peraturan, Panti Asuhan Muhammadiyah Mojokerto memiliki program-program untuk pembekalan karakter anak. Penelitian ini bertujuan untuk mengetahui implikasi dari penanaman nilai-nilai akhlakul karimah kepada anak asuh. Desain penelitian yang dipakai adalah kualitatif, dengan metode pengumpulan data yaitu observasi, wawancara, dan dokumentasi. Teknik analisis data dengan Flow Model yang meliputi reduksi data, display data, penarikan kesimpulan.Kesimpulan penelitian ini adalah:proses penanaman nilai karakter panti asuhan dengan menanamkan nilai akhlakhul karimah melalui pendekatan religius, nilai budaya, lingkungan, potensi diri, dan keseharian. Implikasinya yaitu anak asuh mendapatkan pembelajaran ilmu yang baru yang dapat merubah kesehariannya menjadi lebih baik. Faktor penghambatnya adalah lingkungan asalnya yang kurang baik dikarenakan banyaknya anak-anak nakal dan kurang mendapatkan penanaman nilai akhlakul karimah sejak kecil dari orang tuanya.

Kata Kunci: Internalisasi, nilai-nilai akhlak, pendekatan lingkungan.

Abstract: The Muhammadiyah Dlanggu Orphanage Mojokerto is a place to educate children who are disadvantaged in teaching from their parents, because of problems from 40 children, some who disobey, who like to disobey the rules, the Muhammadiyah Orphanage Mojokerto has programs for character briefing child. This study aims to determine the implications of the cultivation of moral values to foster children. The research design used is qualitative, with data collection methods namely observation, interviews, and documentation. Data analysis techniques with Flow Model which includes data reduction, data display, conclusion. The conclusions of this study are: the process of planting the character values of an orphanage by instilling the value of akhlakhul karimah through a religious approach, cultural values, environment, self potential, and daily life. The implication is that foster children get new knowledge learning that can change their daily lives for the better. The inhibiting factor is that the origin of the environment is not good because of the number of naughty children and lack of cultivation of moral values since childhood from their parents.

Keywords: Internalization, moral values, environmental approach. 


\section{Ali Muhsin}

\section{A. Pendahuluan}

Anak merupakan bagian terpenting dalam kelangsungan hidup manusia, karena anak sebagai generasi penerus dalam sebuah keluarga. Sejak lahir anak diperkenalkan dengan pranata, aturan, norma, dan nilai-nilai budaya yang berlaku melalui pembinaan yang diberikan oleh orang tua dalam keluarga. Orang tua sebagai pendidik sekaligus sekolah pertama bagi anak, harus mendidik anak aga memiliki sikap serta karakter yang baik. Karakter adalah mustika hidup yang membedakan manusia dengan binatang. Manusia tanpa karaker adalah manusia yang sudah "membinatangkan" (Zubaedi, 2011;1).

Orang yang berkarakter kuat dan baik secara individual maupun sosial ialah mereka yang meiliki akhlak, moral, dan budi pekerti yang baik. Peran orang tua sangatlah penting dalam membentuk karakter anak. Akan tetapi tidak dapat dipungkiri bahwa tiddak semua anak memiliki orang tua yang sempurna, bahkan tidak sedikit pula anak tanpa orang tua atau anak yatim piatu. Anak yatim tidak bisa merasakan peran orang tua untuk membentuk karakternya, mereka membutuhkan sosok lain untuk menggantikan peran orang tua. Salah satu cara yang dilakukan agar anak yatim tetap dalam pengasuhan adalah menampung anak-anak tersebut dalam suatu wadah, yaitu panti asuhan guna untuk meningkatkan kesejahteraan anak dengan cara mendidik, merawat, membimbing, mengarahkan, dan memberikan keterampilan-ketarampilan seperti yang diberikan oleh orang tua dalam keluarga. Panti asuhan sebagai lembaga yang menaungi serta didalamnya memiliki peran membimbing dan mendidik memeliki peran yang sangat penting dalam proses mengarahkan dan mendidik, agar anak memiliki karakter yang baik. Sehingga saat tumbuh dewasa anak menjadi orang yang bermartabat.

\section{B. Metode Penelitian}

Jenis penelitian ini adalah penelitian lapangan (Field Research) yaitu penelitian yang terjun langsung ke lokasi untuk memperoleh data terkait dengan penelitian yang dilakukan. Penelitian ini menggunakan pendekatan deskriptif kualitatif dengan menggambarkan dan menginterpretasikan kondisi apa adanya sesuai dengan realitas di lapangan terkait dengan Internalisasi nilai-nilai akhlakul karimah dalam membentuk karakter anak di Panti Asuhan Muhammadiyah Sumberkarang Dlanggu Mojokerto. Teknik pengumpulan data pada penelitian ini yakni, wawancara, observasi, dan 
dokumentasi. Teknik analisis data yang peneliti gunakan yaitu Flow model, yang meliputi reduksi data, display data, dan penarikan kesimpulan. Adapun subjek dalam penelitian ini yaitu, pengasuh, pengurus dan anak-anak yang tinggal di Panti Asuhan. Dan objek dari penelitian ini adalah Internalisasi nilai-nilai akhlakul karimah dalam membentuk karakter anak di Panti Asuhan Muhammadiyah Sumberkarang Dlanggu Mojokerto.

\section{Hasil dan Pembahasan}

Penanaman nilai karakter anak di panti asuhan Muhammadiyah membentuk anak menjadi individu yang memiliki karakter baik sesuai dengan ajaran agama Islam, dalam kenyataanya menanamkan nilai karakter anak membutuhkan suatu konsep yang matang sehingga anak dapat menerima dan merefleksikan diri pendidikan yang di berikan oleh pengasuh. Sesuai hasil penelitian tersebut menunjukkan konsep nilai-nilai karakter menurut Balitbang Kemendiknas (2010:7) sesuai dengan nilai karakter yang di tanamkan di panti asuhan Muhammadiyah yaitu:

1. Menanamkan nilai keagamaan

Panti asuhan Muhammadiyah menanamkan nilai agama dengan cara menggunakan pendidikan bermodel pondok pesantren. Dalam menekankan pendidikan panti asuhan yaitu menjunjung tinggi ajaran agama Islam. Pengasuh juga membiasakan anak asuh untuk tetap menjunjung nilai agama yang di milikinya sejak lahir hingga sekarang, karena dengan pendidikan agama kepribadian mereka akan terbentuk dengan baik sesuai syari'at islam.

Panti asuhan memiliki berbagai upaya dalam menanamkan nilai religius/agama yaitu: (1) peringatan hari besar keagamaan seperti peringatan bulan suci ramadhan (2) sholat berjamaah (3) membiasakan mengucapkan salam ketika di luar panti asuhan (4) menegur santri yang tidak menjawab salam (5) menyediakan fasilitas untuk beribadah dan mengikuti pembelajaran seperti hadroh, tes baca tulis Al-Quran, serta bahasa arab, (6) memasang berbagai slogan, poster, dan kaligrafi ayat suci Al-quran.

Berdasarkan hasil dari observasi tersebut dapat diketahui bahwa pengasuh menanamkan nilai keagamaan melalui berbagai upaya yaitu membiasakan sholat berjamaah, membiasakan mengucapkan salam dan menjawab 


\section{Ali Muhsin}

salam, membaca hafalan bacaan yang di wajibkan, mengintegrasikan kedalam kehidupan sehari hari bahwa agama merupakan kunci menjalankan suatu kehidupan.Salah satu cara membentuk akhlak anak sejak kecil, orang tua perlu membiasakan anaknya untuk melakukan perilaku tertentu (Abdul mustaqim, 2007;7).

2. Menanamkan sikap jujur pada anak panti asuhan

Perilaku yang didasarkan pada upaya menjadikan dirinya sebagai orang yang selalu dapat dipercaya dalam perkataan, tindakan, dan pekerjaan. Upaya dalam membiasakan anak agar berperilaku jujur pengasuh memberikan contoh dengan cara menjadi tauladan bagi anak dan memberi stimulasi terhadap anak, jadi anak tidak merasa di jadikan robot yang selalu diperintah dan dipaksa dalam melakukan segala kegiatan.

3. Menanamkan sikap toleransi pada anak asuh

Pengasuh di dalam panti asuhan memberikan kesempatan belajar memahami segala sesuatu untuk dapat hidup secara toleransi kepada sesama temanya. dalam Al-Qur'an juga sudah di jelaskan bahwa Allah menciptakan manusia untuk saling menghargai dan menghormati satu sama yang lain. Karena sikap toleransi juga di anjurkan untuk menghargai berbagai suku, bangsa, agama di belahan dunia ini. Panti Asuhan Muhammadiyah sangat menanamkan sikap ini untuk membentuk sikap dan perilaku saling menghargai agar menjadi lebih baik dalam mengenal sesama manusia, karena kita tidak dapat hidup sendiri melainkan bantuan dari sesama manusia untuk membangun suatu kehidupan yang harmonis.

Menanamkan disiplin pada anak, disiplin merupakan tindakan yang yang menunjukkan perilaku tertib dan patuh pada berbagai ketentuan dan peraturan.Karena dalam meningkatkan sikap disiplin mengakibatkan sikap dan perilaku seseorang yang mencerminkan ketaatan/kepatuhan terhadap semua aturan.Penanaman serta pembekalan karakter untuk anak usia dini sangatlah penting, pendidikan karakter sejak kecil dan secara konsisten (La Hadisi, 2015). Nilai ini dapat di tanamkan melalui pembiasaan mentaati peraturan yang ada di panti asuhan. 
4. Menanamkan sikap Kerja Keras pada anak asuh

Dalam pendidikan karakter yang di berikan oleh pengasuh kerja keras merupakan tauladan dari pengasuh. pendidikan karakter yang merupakan nilai kerja keras merupakan bentuk usaha dari pengasuh dalam membangun mental anak asuh untuk dapat bekerja keras dan bersungguh-sungguh dalam melakukan pekerjaan apapun. Semangat untuk bekerja keras hendaknya di imbangi dengan kecerdasan dan keihklasan dalam melakukan pekerjaan. Panti Asuhan Muhammadiyah menanmkan nilai kerja keras itu dengan menilai kesungguh-sungguhan anak asuh dalam belajar dan berkarya.

5. Menanamkan nilai kreatif pada anak asuh

Kreatif merupakan berfikir dalam melakukan sesuatu untuk cara atau hasil dari suatu yang telah dimiliki. Upaya seseorang untuk mengoptimalkan potensi yang dia miliki dengan cara menciptakan suatu yang baru dari suatu yang telah ada, nilai kreatif dapat di ciptakan dengan cara menumbuhkan daya fikir dan bertindak kreatif, serta memberikan tugas yang menjadikan tantangan adanya karya baru.

6. Menanamkan sikap mandiri untuk anak asuh

Dalam melatih kemandirian anak asuh Panti Asuhan Muhammadiyah merupakan hal yang tidak mudah untuk di bangun dalam diri seseorang. Orang yang mandiri adalah orang yang cukup diri, yaitu mampu berfikir dan bertindak atas keputusannya sendiri, tidak perlu bantuan orang lain, berani mengambil resiko, serta mampu menyelesaikan masalah. pendidikan akhlakul karimah untuk membentuk karakter mengajarkan untuk bersikap mandiri baik dalam hal pekerjaan maupun kegiatan lainya. Islam mengajarkan untuk bersikap mandiri dan tidak manja.

7. Menanamkan rasa ingin tau pada anak asuh

Rasa ingin tahu adalah sikap dan tindakan yang selalu berupaya untuk mengetahui lebih mendalam dan meluas dari sesuatu yang dipelajarinya, dilihat, dan didengar (La Hadisi, 2015). Dalam pengasuhan di Panti Asuhan Muhammadiyah pengasuh melatih anak asuh untuk selalu bersikap dan berupaya untuk mengetahui lebih mendalam dan meluas dari sesuatu yang di pelajari. Panti Asuhan Muhammadiyah menanamkan nilai rasa ingin tahu di tanamkan oleh 


\section{Ali Muhsin}

pengasuh sejak dini untuk melatih emosi seseorang yang ada dalam diri seseorang untuk mengetahui secara lebih mendalam

Adapun kegiatan-kegiatan harian yang dilaskukan olh anak selama di Pati Asuhan (1) Pengajian Diniyah Kegiatan ini dilaksanakan setiap hari kecuali hari minggu, dimulai dari pukul 04.30-06.00 pagi, adapun kitab-kitab yang dikaji adalah kitab yang erisi tentang fiqh atau syariah, tauhid, bahasa, ahklaq, tasawuf, dan lainlain. (2) Pengajian umum Kegiatan ini dilaksanakan setiap minggu ke dua dengan melibatkan masyarakat umum sekaligus anak asuh panti, dengan penceramah yang sudah ditetapkan oleh pengurus panti. Acara ini dimulai pukul 20.00-21.00, di masjid panti asuhan.(3) Keterampilan-keterampilan Keterampilan ini dilakukan setiap hari minggu sekali yang dilaksanakan oleh seluruh anak asuh, keterampilan yang diajarkan meliputi: menjahit, memasak, kaligrafi, komputer, tapak suci, seni baca al quran, dan juga anak asuh diberi pembelajaran dalam menegement dengan dibangunkan koperasi panti yang menjual bahan-bahan pokok untuk masyarakat dan juga untuk anak asuh laki-laki mereka setiap individu diberi tanggung jawab untuk memelihara kambing yang nanti dapat dikembang biakna oleh merka sendiri dan hasilnya untuk mereka sendiri. (4) Sekolah formal Semua anak asuh Panti Asuhan Muhammadiya sumberkarang Dlanggu Mojokerto disamping mengikuti kegiatan yang telah diselenggarakan mereka juga mengikuti sekolah formal, baik ditingkat SD, SMP/MTS, SMA/MA/SMK dan juga dijenjang perguruan tinggi.

a. Faktor Penghambat Proses Internalisasi Pendidikan Akhlakul Karimah Kepada Anak Asuh.

1. Pengaruh teman sebaya di luar panti asuhan. Teman-teman sebaya anak di luar panti asuhan juga dapat mempengaruhi akhlak anak. Untuk menanggulangi masalah ini maka pengurus panti asuhan bekerja sama dengan pihak sekolah untuk mengetahui jadwal kegiatan anak asuh di sekolah. Agar pengurus mengetahui mana yang berkata jujur dan bohong.

2. Sifat dan watak anak asuh yang susah di atur, sifat dan watak anak juga berpengaruh dalam menanamkan pendidikan akhlakul karimah. Hal ini dapat berdampak buruk apabila anak asuh memiliki sifat keras kepala dan 
susah di atur juga termsuk penghambat dalam menanamkan pendidikan akhlakul karimah.

b. Faktor pendukung Proses Internalisasi Pendidikan Akhlakul Karimah Kepada Anak Asuh

Panti Asuhan Muhammadiyah merupakan panti asuhan yang membimbing dan mendidik anak asuh yang kurang beruntung yaitu anak yatim, piatu, yatim dan piatu, dan fakir miskin. Ada faktor pendukung dalam pendidikan karakter yang di berikan dan di ajarkan untuk anak asuh, faktor pendukung dari pembentukan karakter itu adalah panti asuhan yang berbasis pondok pesantren jadi anak asuh tersebut mendapatkan pengasuhan pendidikan ilmu agama dan pendidikan karakter untuk diri anak. Anak asuh yang mendapat pengasuhan di dalam panti asuhan ini akan mengikuti semua kegiatan yang berbau pondok pesantren. kebiasaan baik juga di berikan pengasuh untuk membimbing dan memberi contoh positif dalam kegiatan sosial.

c. Proses Penanaman Nilai Karakter Anak di Panti Asuhan Muhammadiyah Sumberkarang Dlanggu Mojokerto

Pelayanan yang diperoleh anak asuh diantaranya yaitu pemenuhan pendidikan, pemenuhan sandang, papan, pangan, dan pemenuhan kesehatan. Latar belakang anak yatim, piatu, yatim piatu, anak kurang mampu dan anak dalam masalah sosial membuat mereka lebih baik mendapatkan pendidikan di Panti Asuhan Muhammadiyah Sumberkarang Dlanggu Mojokerto. Apalagi di panti menekankan nilai keagamaan yang menjujung tinggi akidah akhlak. Sehingga mereka dapat mengerti dan mengetahui serta dapat menyebar luaskan ilmu agama yang mereka dapatkan di panti asuhan.

Dalam menanamkan nilai karakter sangat memperhatikan nilai disiplin diri untuk membentuk anak yang bersikap disiplin baik dalam diri maupun di lingkungan masyarakat. Karena dalam meningkatkan sikap disiplin mengakibatkan sikap dan perilaku seseorang yang mencerminkan ketaatan/kepatuhan terhadap semua aturan (Abdul Mustaqim, 2007; 2). Nilai ini dapat di tanamkan melalui pembiasaan mentaati peraturan yang ada di panti asuhan, pembiasaan mentaati peraturan yang ada di sekolah formal menjadikan 


\section{Ali Muhsin}

anak terbiasa melakukan hal yang baik di dalam dirinya. Panti Asuhan Muhammadiyah memiliki jadwal kegiatan baik dari kegiatan panti asuhan sampai kegiatan di luar sekolah.

Untuk lebih jelasnya berikut merupakan diskripsi tentang analisis nilai disiplin terhadap anak asuh: (1) Bangun pagi dan sholat berjamaah dengan tepat waktu, (2) Memberikan sanksi bagi yang melanggar tata tertib panti, (3) Memberikan contoh untuk berpakaian rapi dan sopan sesuai syariah islam. (4) memasang tata tertib yang mudah di baca oleh anak asuhdan mengajak anak asuh untuk menggunakan waktu sebaik mungkin.

1. Menanamkan Sikap Kerja Keras Pada Anak Asuh

Dalam menanamkan nilai karakter kerja keras adalah perilaku yang menunjukkan upaya sungguh-sungguh dalam mengatasi hambatan belajar dan tugas, serta menyelesaikan tugas dengan baik. Dalam pendidikan karakter yang di berikan oleh pengasuh kerja keras merupakan tauladan dari pengasuh. Penanaman nilai kerja keras terhadap siswa dilakukan melalui keteladanan, pengkondisian, dan aktifitas yang ada di lingkungan panti asuhan.

2. Menanamkan Nilai Kreatif Pada Anak Asuh

Kreatif merupakan berfikir dalam melakukan sesuatu untuk menghasilkan cara atau hasil dari suatu yang telah dimiliki. Upaya seseorang untuk mengoptimalkan potensi yang dia miliki dengan cara menciptakan suatu yang baru dari suatu yang telah ada, nilai kreatif dapat di ciptakan dengan cara menumbuhkan daya fikir dan bertindak kreatif, serta memberikan tugas yang menjadikan tantangan adanya karya baru.

d. Perubahan Sikap dan Perilaku Anak Asuh di Panti Asuhan Muhammadiyah Sumberkarang Dlanggu Mojokerto.

Latar belakang anak asuh yang berda di panti asuhan Muhammadiyah rata-rata berada di kalangan yang kurang beruntung, melainkan mereka merupakan anak yatim, piatu, yatim dan piatu sehingga anak asuh di panti asuhan Muhammadiyah memiliki berbagai persoalan dalam lingkungan keluarga mereka, antara lain yaitu belum memahami nilai ajaran agama Islam, sikap yang arogan, tidak mempunyai sopan santun, tidak percaya diri, 
pendidikan rendah, banyaknya tekanan yang datang dari dalam maupun luar, pendidikan karakter yang belum di berikan, sehingga mereka diberikan pendidikan di panti asuhan berlandaskan Al-qur'an dan hadis untuk membangun karakter positif dari dalam dirinya.

Pertama kali masuk di Panti Asuhan Muhammadiyah masih membawa sikap asli mereka di lingkungan rumah, karena setiap keluarga pasti berbeda cara mendidiknya. Di panti asuhan Muhammadiyah ini mereka diajarkan dan dibimbing ke arah yang lebih baik sesuai dengan ajaran agama, karena pada dasarnya manusia memiliki sikap yang baik tetapi tergantung dari lingkungan mereka berada apakah berada di lingkungan yang menunjukkan karakter yang baik apa tidak.Karena karakter adalah mustika hidup yang membedakan manusia dengan binatang (Zubaedi, 2011;1). Sehingga setelah mereka mengikuti berbagai kegiatan yang di berikan oleh panti asuhan mereka sadar bagaimana pentingnya melakukan sesuatu yang positif, pembawaan mereka juga lebih tenang bahkan mereka selalu sopan dengan semua orang yang lebih tua, lebih menyayangi yang muda.Anak asuh yang memasuki dunia panti asuhan yang berhembuskan pondok pesantren ini merasakan hal positif selalu di ajarkan di lingkungan panti asuhan, karena pada dasarnya pendidikan di panti asuhan ini berlandaskan ilmu agama yaitu Al-qur'an dan hadis. Pendidikan karakter juga di berikan untuk menunjang bagaimana perilaku anak yang baik di tanamkan, dan hasilnya memang anak menjadi lebih terarah dengan pendidikan yang diberikan di lingkungan panti asuhan Muhammadiyah Sumberkarang Dlanggu Mojokerto.Batasan ini menunjukkan bahwa karakter sebagai identitas yang dimiliki seseorang yang bersifat menetap dan menjadikan lebih terarah (Anita Yus, 2008; 91).

e. Pengasuhan anak melalui akhlakul karimah dalam membentuk karakter anak di Panti Asuhan Muhammadiyah Sumberkarang Dlanggu Mojokerto

Setiap anak asuh memiliki hak untuk mendapatkan pelayanan pengasuhan pendidikan karakter, karena pendidikan karakter sangat berguna untuk kelangsungan hidupnya, baik untuk diri sendiri maupun untuk orang lain.Dalam mendukung pendidikan karakter di perlukan fasilitas untuk anak asuh yaitu dengan cara memberikan pendidikan melalui landasan ilmu agama 


\section{Ali Muhsin}

yaitu Al-Quran dan Hadis, seta kebiasaan (Anita Yus, 2008; 91). kebiasaan baik yang di tanamkan pengasuh juga sangat mempengaruhi anak asuh dalam perkembangan karakter mereka. Pendidikan karakter yang ditanamkan di panti Muhammadiyah Sumberkarang Dlanggu Mojokerto adalah pendidikan agama meliputi landasan Al-qur'an dan Hadis karena dengan landasan tersebut pendidikan karakter akan tersampaikan, sehingga anak asuh dapat menerima apa yang di berikan oleh pengasuh. Dalam menyampaikan pendidikan karakter tersebut pengasuh menggunakan metode ceramah setelah mengaji dan memberikan tauladan dalam kehidupan sehari-hari, dan pengasuh juga memberikan pendidikan demokratis untuk anak supaya cara pikir mereka lebih berkembang.

Pengasuh memberikan pola pengasuhan demokratis dalam mengasuh dan mendidik anak asuh dikarenakan pengasuh ingin anak asuhnya menjadi anak yang dapat memberikan berbagai masukan dengan maksud untuk menjadikan anak lebih percaya diri, dan pengasuh hanya memberikan pengarahan. Manfaat yang di rasakan oleh anak asuh panti asuhan Muhammadiyah Sumberkarang Dlanggu Mojokerto sangat banyak, karena mereka selalu di bimbing dan di dampingi dalam mengerjakan hal yang positif. Nilai agama yang di landasi Alqur'an dan Hadis juga di sampaikan secara terang-terangan untuk mendapatkan hasil yang maksimal. Pengasuh juga memberikan tauladan bagi anak asuh di lingkungan panti asuhan sehingga mereka dapat menerima dengan baik ajaran yang di berikan di panti asuhan yang bernafaskan pondok pesantren.

Nilai karakter yang di tanamkan di panti asuhan meliputi pendidikan agama memang dalam kenyataanya di dalam panti asuhan tersebut lebih menekankan nilai karakter antara lain: (a) Ilmu agama yang diberikan di panti asuhan adalah memperdalam akhlaqul karimah sebagai landasannya yaitu AlQur'an dan Hadis. (b) menanamkan sikap jujur dipanti asuhan tersebut anak asuh di tuntut untuk bersikap jujur dalam segala bentuk kegiatan baik di lingkungan panti asuhan maupun di luar panti. (c) Menanamkan sikap toleransi dalam bergaul dengan sesama teman jadi mereka lebih menghargai teman mereka yang ada di panti dengan begitu suasana kekeluargaan akan semakin erat. (d) Menanamkan sikap disiplin itu diterapkan di panti asuhan di setiap 
ruangan anak asuh di berikan jadwal kegiatan dan tata tertib di lingkungan panti asuhan. (e) Panti asuhan Muhammadiyah dalam menanamkan nilai kerja keras di tunjukkan dalam bentuk menyelesaikan tugas sekolah dan tugas panti dengan sungguh-sungguh. (f) Menanamkan nilai kreatif yang di berikan oleh Panti Asuhan Muhammadiyah adalah dengan memberikan pelatihan wirausaha sesuai dengan kemauan mereka. (g) Menanamkan nilai tanggung jawab di panti asuhan dengan memberikan tugas untuk anak asuh seperti membersihkan ruangan dan lingkungan sesuai jadwal.

f. Perubahan Sikap dan Perilaku Anak Asuh di Panti Asuhan Muhammadiyah Sumberkarang Dlanggu Mojokerto

Latar belakang anak asuh yang berda di panti asuhan Muhammadiyah rata-rata berada di kalangan yang kurang beruntung, melainkan mereka merupakan anak yatim, piatu, yatim dan piatu sehingga anak asuh di panti asuhan Muhammadiyah memiliki berbagai persoalan dalam lingkungan keluarga mereka, antara lain yaitu belum memahami nilai ajaran agama Islam, sikap yang arogan, tidak mempunyai sopan santun, tidak percaya diri, pendidikan rendah, banyaknya tekanan yang datang dari dalam maupun luar, pendidikan karakter yang belum di berikan, sehingga mereka diberikan pendidikan di panti asuhan berlandaskan Al-qur'an dan hadis untuk membangun karakter positif dari dalam dirinya.

Pertama kali masuk di Panti Asuhan Muhammadiyah masih membawa sikap asli mereka di lingkungan rumah, karena setiap keluarga pasti berbeda cara mendidiknya. Di panti asuhan Muhammadiyah ini mereka diajarkan dan dibimbing ke arah yang lebih baik sesuai dengan ajaran agama, karena pada dasarnya manusia memiliki sikap yang baik tetapi tergantung dari lingkungan mereka berada apakah berada di lingkungan yang menunjukkan karakter yang baik apa tidak.Karena karakter adalah mustika hidup yang membedakan manusia dengan binatang (Zubaedi, 2011;1). Sehingga setelah mereka mengikuti berbagai kegiatan yang di berikan oleh panti asuhan mereka sadar bagaimana pentingnya melakukan sesuatu yang positif, pembawaan mereka juga lebih tenang bahkan mereka selalu sopan dengan semua orang yang lebih tua, lebih menyayangi yang muda.Anak asuh yang memasuki dunia panti 


\section{Ali Muhsin}

asuhan yang berhembuskan pondok pesantren ini merasakan hal positif selalu di ajarkan di lingkungan panti asuhan, karena pada dasarnya pendidikan di panti asuhan ini berlandaskan ilmu agama yaitu Al-qur'an dan hadis. Pendidikan karakter juga di berikan untuk menunjang bagaimana perilaku anak yang baik di tanamkan, dan hasilnya memang anak menjadi lebih terarah dengan pendidikan yang diberikan di lingkungan panti asuhan Muhammadiyah Sumberkarang Dlanggu Mojokerto.Batasan ini menunjukkan bahwa karakter sebagai identitas yang dimiliki seseorang yang bersifat menetap dan menjadikan lebih terarah (Anita Yus, 2008; 91).

\section{Kesimpulan.}

Berdasarkan uraian dari hasil penelitian dan pembahasan yang telah dilakukan, maka peneliti dapat menarik kesimpulan sebagai berikut: (1) Proses penanaman nilai karakter di Panti dan pondok pesantren Asuhan Muhammadiyah yaitu menanamkan pendidikan akhlakhul karimah melalui pendekatan religius, nilai budaya, lingkungan, potensi diri yang dilaksankan melalui sikap dan keseharian seperti mejalankan ibadah, siraman rohani, membersihkan lingkungan, memberikan bimbingan keterampilan. (2) Nilai karakter yang ditanamkan di panti asuhan Muhammadiyah yaitu meliputi nilai religius, jujur, disiplin, toleransi, mandiri, rasa ingin tahu, tanggung jawab. Proses pengasuhan menekankan nilai akhlakul karimah di panti asuhan Muhammadiyahyaitu melalui perencanaan kegiatan, pelaksanaan menggunakan metode, media dan materi, dan evaluasi. (3) Faktor penghambat dalam menanamkan karakter anak asuh adalah asal mula anak asuh tidak berasal dari lingkungan yang membuat karakter mereka baik,kebiasaan di rumah mereka yang kurang mendukung adanya pendidikan akhlakul karimah dikarenakan mereka anak yatim piatu, yatim, piatu, kurang mampu. Faktor pendukung dalam menanamkan pendidikan akhlakul karimah adalah anak asuh senantiasa mengikuti proses pengasuhan yang diberikan, mendapat ilmu pendidikan agama yang cukup karena di panti ini menggunakan pembelajaran dan pengasuhan seperti pondok pesantren. 


\section{Daftar Pustaka}

Arikunto, suharsimi. 2006. Prosedur penelitian suatu pendekatan praktek. Jakarta: rineka cipta.

Asliyah, zulehatun. 2014. Nilai-nilai pendidikan karakter dalam mata pelajaran PAI di SMPN 1 Karang Mancol Purbalingga. "Skripsi” UNEJ, Jember.

Departemen agama republik Indonesia. 2005. Mushaf al-quran terjemah. Jakarta: Gema insani.

Depdikbud. 1989. Kamus besar Bahasa indonesia. Jakarta: Balai Pustaka.

J. Moleong, Lexy. 2014. Metode penelitian kualitatif. Bandung: PT Remaja Rosdakarya.

Langgulung, Hasan. 1980. Asas-asas pendidikan islam. Jakarta: Radar jaya offset.

Mahmudah, Umi. 2010. Internalisasi nilai-nilai pendidikan agama islam pada pembelajaran PAI di SMPN 1 nusawungu cilacap. "Skripsi". UIN Syarif Hidayatulloh, Jakarta.

Muhaimin. 1996. Strategi belajar mengajar. Surabaya: Citra media.

Mustangin. 2009. Internalisasi pendidikan akhlak melalui metode pembiasaan dan teladan di MTsN Tambok Banyumas. "Skripsi" Universitas Negeri Semarang, Semarang.

Mustaqin, abdul. 2007. Akhlak tasawuf. Yogyakarta: Kreasi wacana.

Nasution, S. 2009. Metode research (penelitian ilmiah). Jakarta: Bumi Aksara.

Rianto, yatim. 1996. Metodelogi penelitian pendidikan tinjauan dasar. Surabaya: SIC.

Sugiono. 2009. Metode penelitian kuantitatif kualitatif dan R\&D. Bandung: CV Alfabeta.

Yus, anita. 2008. Pengembangan karakter melalui hubungan anak-kakek-nenek. Yogyakarta: Tiara wacana.

Zubaedi. 2011. Desain pendidikan karakter. Jakarta: Kencana.

Zuhairini. 1991. Filsafat pendidikan islam. Jakarta: Bumi Aksara.

La Hadisi, 2015, "Pendidikan Karakter Pada Anak Usia Dini”, jurnal al-Ta'dib, vol 8, No 2 Juli-Desember 
Ali Muhsin

Nila A'inu Ningrum," hubungan antara copling strategi dengan kenakalan remaja awa", jurnal psikolog, No. 1, April:481-4891, 2012. 